\title{
Reduction of bleomycin induced lung fibrosis by transforming growth factor $\beta$ soluble receptor in hamsters
}

Qingjian Wang, Yinjin Wang, Dallas M Hyde, Philip J Gotwals, Victor E Koteliansky, Sarah T Ryan, Shri N Giri

\begin{abstract}
Background-Transforming growth factor $\beta($ TGF $-\beta)$ is a key mediator of collagen synthesis in the development of lung fibrosis. It has previously been shown that the administration of TGF- $\beta$ antibody and TGF- $\beta$ binding proteoglycan, decorin, reduced bleomycin (BL) induced lung fibrosis in animals. The present study was carried out to investigate whether intratracheal instillation of TGF- $\beta$ soluble receptor (TR) would minimise the $B L$ induced lung fibrosis in hamsters.

Methods-The effect of a recombinant TR (TGFßRII) on the lung collagen accumulation was evaluated in a BL hamster model of pulmonary fibrosis. Animals were divided into four groups and intratracheally injected with saline or $B L$ at $6.5 \mathrm{U} / 4 \mathrm{ml} / \mathrm{kg}$ followed by intratracheal instillation of phosphate buffered saline (PBS) or $4 \mathrm{nmol}$ TR in $0.3 \mathrm{ml}$ twice a week. Twenty days after the first intratracheal instillation the hamsters were killed for bronchoalveolar lavage (BAL) fluid, biochemical, and histopathological analyses.
\end{abstract}

Results-Treatment of hamsters with TR after intratracheal instillation of $B L$ significantly reduced BL induced lung fibrosis as shown by decreases in the lung hydroxyproline level and prolyl hydroxylase activity, although they were still significantly higher than those of the saline control. Histopathological examination showed a considerable decrease in BL induced fibrotic lesions by TR treatment. However, TR did not prevent the BL induced increases in total cells and protein in the BAL fluid.

School of Veterinary Medicine, University of California, Davis, California 95616, USA

Biogen Inc,

Cambridge,

Massachusetts 02142,

USA

P J Gotwals

V E Koteliansky

S T Ryan

Correspondence to:

Dr S N Giri.

Received 1 February 1999

Returned to author

29 March 1999

Revised manuscript received

4 May 1999

Accepted for publication

21 May 1999
Interstitial pulmonary fibrosis (IPF) is a crippling disease that leads to a reduction of lung compliance and impairment of the vital gas exchange function due to an excess accumulation of collagen in the interstitium resulting from inflammatory and fibroprolif- erative changes of the lung. ${ }^{1}$ IPF may result from a wide range of processes including the use of bleomycin (BL) in chemotherapy. The pneumotoxic effect of BL has been used to generate reproducible pulmonary fibrosis in animals. ${ }^{2}$ Intratracheal instillation of $\mathrm{BL}$ in hamsters has been shown to cause lung fibrosis similar to that seen in humans and therefore this model has been widely used for studying mechanisms of fibrogenesis and for screening potentially desirable antifibrotic compounds. ${ }^{3-5}$

The mechanisms of BL induced pulmonary injury and the subsequent development of fibrosis are not completely understood. BL is known to generate reactive oxygen species upon binding to DNA and iron which cause DNA damage. ${ }^{6}$ The interaction of $\mathrm{BL}$ with DNA appears to initiate the inflammatory and fibroproliferative changes via a concerted action of various cytokines, leading to accumulation of collagen in the lung. One of the most important mediators of collagen synthesis is transforming growth factor $\beta$ (TGF- $\beta$ ) which is known to stimulate collagen production. ${ }^{78}$ While TGF- $\beta_{1}$, TGF- $\beta_{2}$, and TGF- $\beta_{3}$ all exert profibrotic effects in vitro, TGF- $\beta_{1}$ appears to be the predominant isoform expressed during experimental pulmonary fibrosis. ${ }^{9}$ TGF- $\beta$ stimulates procollagen gene transcription, increases mRNA stability, and decreases intracellular degradation of procollagen. ${ }^{10-12}$ In animal models of pulmonary fibrosis the levels of TGF- $\beta$ mRNA and protein were increased. ${ }^{13-15}$ Immunohistochemical staining of the lung after instillation of BL showed a patchy localisation of TGF- $\beta$ initially in the subepithelial matrix followed by intense staining of macrophages, and later intense staining was observed at the edges of areas of repair with hypercellularity and collagen deposition. ${ }^{16}$ Furthermore, TGF- $\beta$ antagonists in the form of neutralising antibody or the TGF- $\beta$ binding proteoglycan, decorin, reduced BL induced lung fibrosis. ${ }^{17} 18$

In mammalian cells the response to TGF- $\beta$ is mediated by type I and type II cell surface receptors with cytoplasmic serine/threonine kinase domains. ${ }^{19} 20$ The type II signalling receptors (TRIIs) are specific for their respective ligands and promote ligand specific function. ${ }^{21}$ TRII is a constitutively active kinase which is recognised by TRI only after ligand binding to TRII and, subsequently, TRI is recruited into the complex and phosphorylated by TRII. ${ }^{22}$ TGF- $\beta$ binds directly to TRII, allowing this receptor to associate with and phosphorylate TRI which then propagates the 


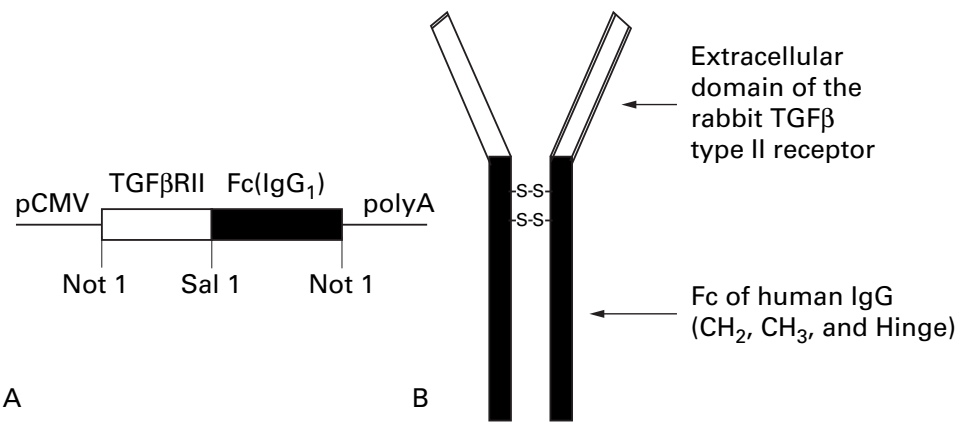

Figure 1 pTGFßR:Fc $(A)$ was generated by cloning the extracellular domain of the rabbit type II TGF- $\beta$ receptor and the $F c$ region of human Ig $G_{1}$ downstream of a cytomegalovirus ( $p C M V$ ) promoter (see text for details). Expression of $p T G F \beta R$ : $F$ c results in a dimeric form of the receptor: $F c$ fusion protein (B). $P=$ plasmid.

signal. ${ }^{23}$ In this respect, a soluble version of the TGF- $\beta$ receptor may prevent the interaction of TGF- $\beta$ with the cell surface receptor, thereby neutralising TGF- $\beta$ activity. ${ }^{24}{ }^{25}$ Indeed, it has been shown that the soluble extracellular domain of TRII is able to neutralise the inhibitory activity of TGF- $\beta$ on cell proliferation in vitro. ${ }^{26}$ In searching for TGF- $\beta$ antagonists we have generated a chimeric TGF- $\beta$ soluble receptor that has high affinity for TGF- $\beta$ but lacks the ability to initiate signal transduction events necessary for function. In this paper we show that the TGF- $\beta$ soluble receptor has antifibrotic potential in animals.

\section{Methods}

MATERIALS

Pathogen free male Golden Syrian hamsters weighing 120-130 g were purchased from Simonsen Inc (Gilroy, California, USA); bleomycin sulfate (Blenoxane) was a gift from Bristol Laboratories (Syracuse, New York, USA);

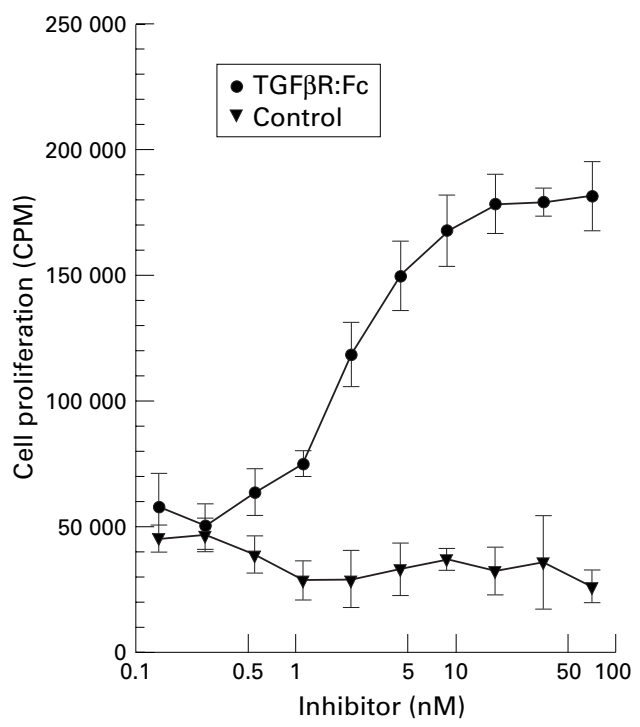

Figure 2 TGF $\beta R$ :Fc relieves TGF- $\beta_{1}$ mediated inhibition of mink lung epithelial cell proliferation. Increasing concentrations of either dimeric TGF $\beta R: F c$ (circles) or monomeric type II TGF- $\beta$ receptor extracellular domain (control, triangles) were incubated with Mv1Lu mink lung epithelial cells in media containing $0.1 \mathrm{ng} / \mathrm{ml} \mathrm{TGF-} \beta_{1}$ and assayed for $\left[{ }^{\beta} H\right]$ thymidine incorporation as described in the text. Data represent the mean (SE) values for six assay wells in counts per minute (CPM). TGFBR:Fc relieved $50 \%\left(I C_{50}\right)$ of TGF- $\beta_{1}$ mediated inhibition of proliferation at a concentration of $2 \mathrm{nM}$.
TGF- $\beta$ soluble receptor as TGF $\beta$ RII was produced as described below at Biogen Inc (Cambridge, Massachusetts, USA); TGF- $\beta_{1}$ was purchased from R\&D Systems (Minneapolis, Minnesota, USA); L- $\left(3,4-{ }^{3} \mathrm{H}\right)$ proline for labelling the procollagen substrate of prolyl hydroxylase was obtained from NEN Life Science Products (Boston, Massachusetts, USA); Z-fix, an aqueous buffered zinc formalin, was purchased from Anatech Ltd (Battle Creek, Michigan, USA). All other reagents were of reagent grade or higher purity and obtained from standard commercial sources.

\section{PRODUCTION OF TGF- $\beta$ SOLUBLE RECEPTOR} TGFßR:FC

The recombinant rabbit TGF $\beta \mathrm{R}: \mathrm{Fc}$ fusion gene (pTGF $\beta \mathrm{R}: \mathrm{Fc}$ ), comprised of the extracellular domain of the rabbit type II TGF- $\beta$ receptor fused to the $\mathrm{Fc}$ portion of human $\mathrm{IgG}_{1}$, was constructed as follows. The extracellular domain of the rabbit type II TGF- $\beta$ receptor was amplified from clone MIS-3f $11^{27}$ by conventional polymerase chain reaction (PCR). Amplified sequences were flanked with a 5' NotI and 3' SalI restriction site and subsequently digested with these restriction enzymes. The human $\mathrm{IgG}_{1} \mathrm{H}$ chain $\mathrm{C}$ region containing the hinge region, the $\mathrm{CH}_{2}$, and $\mathrm{CH}_{3}$ sequences were isolated with $\mathrm{H}$ chain specific primers by PCR amplification as previously described. ${ }^{28}$ Amplified sequences were flanked by a 5' SalI and a $3^{\prime}$ NotI restriction enzyme recognition site and subsequently digested with these restriction enzymes. The receptor and IgG DNA fragments were cloned into the NotI restriction enzyme site in plasmid $\mathrm{SAB} 132^{28}$ and transformed into competent bacteria. Plasmids recovered from the transformants were analysed for the correct orientation of assembled fragments and the entire coding sequence was confirmed by DNA sequencing.

The recombinant rabbit TGF $\beta$ R:Fc fusion gene was transfected into Chinese hamster ovary $(\mathrm{CHO})$ cells. After the initial transfection cells were selected in $250 \mathrm{nM}$ methotrexate. The resulting colonies were expanded and analysed for TGF $\beta$ R:Fc fusion gene expression. Clones expressing the highest levels of TGF $\beta R: F c$ were selected for production of the fusion protein. TGF $\beta R: F c$, which is dimeric, was purified from culture supernatant by protein A-Sepharose affinity chromatography under sterile and endotoxin free conditions.

\section{MINK LUNG EPITHELIAL CELL PROLIFERATION} ASSAY

Mink lung $(\mathrm{Mv} 1 \mathrm{Lu})$ cells were maintained in MEM supplemented with 100 units $/ \mathrm{ml}$ penicillin, $100 \mu \mathrm{g} / \mathrm{ml}$ streptomycin, and $10 \%$ fetal bovine serum. To test, serial dilutions of TGF $\beta$ R:Fc or control (monomeric TGF- $\beta$ receptor type II extracellular domain; R\&D Systems) were incubated with $0.1 \mathrm{ng} / \mathrm{ml}$ TGF- $\beta_{1}$ for one hour in assay medium in a 96-well microtitre tissue culture plate. Mv1Lu cells were resuspended and added to the assay plate at a concentration of 4000 cells per well. The cells were incubated at $37^{\circ} \mathrm{C}$ for 72 hours and pulsed with $\left[{ }^{3} \mathrm{H}\right]$ thymidine (Amersham; 


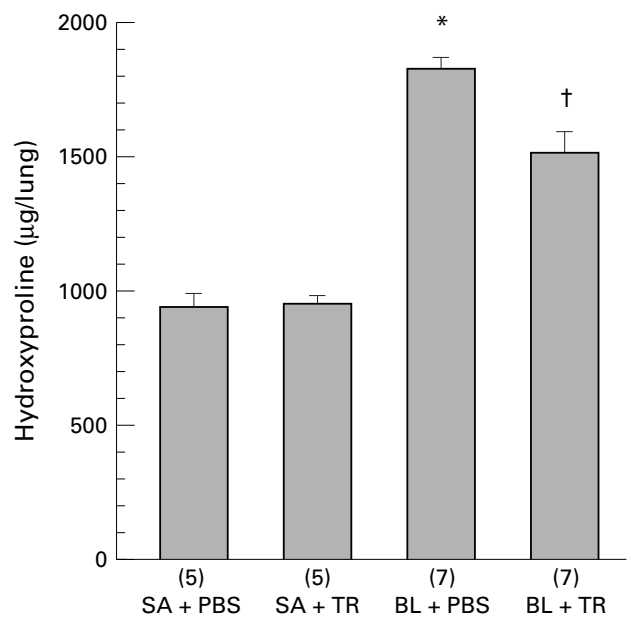

Figure 3 Effects of TGF- $\beta$ soluble receptor treatment on bleomycin induced increases in hydroxyproline content of hamster lungs. The numbers of animals in each group are shown in parentheses along the $x$ axis. $S A+P B S=$ saline + PBS control $; A+T R=$ saline $+T G F-\beta$ soluble receptor; $B L+P B S=$ bleomycin $+P B S ; B L+T R=$ bleomycin $+T G F-\beta$ soluble receptor. Values are expressed as mean (SE). ${ }^{\star} p<0.05$ compared with all other groups; tp $<0.05$ compared with $S A+P B S$ and $S A+T R$ groups.

70-86 Ci/mmol) for an additional four hours. DNA synthesis, which reflects cell proliferation, was determined by measuring incorporation of $\left[{ }^{3} \mathrm{H}\right]$ thymidine.

TREATMENT OF ANIMALS

Hamsters were housed in groups of four in facilities approved by the American Association for the Accreditation of Laboratory Animal Care. All care was in accordance with the National Institute of Health guidelines for animal welfare. The hamsters were allowed to acclimatise in the facilities for one week before all treatments. A 12 hour/12 hour light/dark cycle was maintained and the hamsters had access to water and Rodent Laboratory Chow 5001 (Purina Mills Inc, St Louis, Missouri, USA) ad libitum. The animals were randomly divided into four experimental groups: (1) SA + PBS; (2) SA + TR; (3) BL + PBS; and (4) BL + TR. They were intratracheally injected with a single dose of SA or BL at $6.5 \mathrm{U} / 4 \mathrm{ml} / \mathrm{kg}$ under pentobarbital anaesthesia. Starting two days later, the hamsters received intratracheal instillation of PBS or $4 \mathrm{nmol} \mathrm{TR}$ in $0.3 \mathrm{ml}$ twice a week. Twenty days after the BL instillation they were killed under pentobarbital anaesthesia for bronchoalveolar lavage (BAL) fluid, biochemical, and histopathological analyses.

PREPARATION OF BAL FLUID AND LUNG TISSUE After anaesthesia the abdominal cavity was opened and the descending abdominal aorta exsanguinated. The lungs were prepared for lavage by cannulating the trachea with Teflon tubing attached to a syringe. The lung lavage was carried out with $12 \mathrm{ml}$ of cold isotonic SA delivered in $3 \mathrm{ml}$ aliquots. An aliquot of the BAL fluid was portioned for total and differential cell counting. The remaining BAL fluid was centrifuged at $1500 \mathrm{~g}$ for 20 minutes at $4^{\circ} \mathrm{C}$ and the resulting supernatant aliquoted and stored at $-70^{\circ} \mathrm{C}$. After bronchoalveolar lavage the thoracic cavity was opened and the lung lobes were quickly dissected free of nonparenchymal tissue, immediately frozen in liquid nitrogen, and stored at $-70^{\circ} \mathrm{C}$. The frozen lungs were later thawed and homogenised in $0.1 \mathrm{M} \mathrm{KCl}, 0.02 \mathrm{M}$ Tris ( $\mathrm{pH}$ 7.6) with a Polytron homogeniser (Brinkmann Instruments Inc, Westbury, New York, USA). The homogenate was thoroughly mixed by repeated inversions and the final homogenate volumes $(9-10 \mathrm{ml})$ were recorded. The homogenate was divided into several aliquots and stored at $-70^{\circ} \mathrm{C}$ for biochemical measurements.

DETERMINATION OF HYDROXYPROLINE

For lung hydroxyproline assay $1 \mathrm{ml}$ of homogenate was precipitated with $0.25 \mathrm{ml}$ ice cold $50 \%(\mathrm{w} / \mathrm{v})$ trichloroacetic acid, centrifuged, and the precipitate hydrolysed in $2 \mathrm{ml}$ of $6 \mathrm{~N}$ $\mathrm{HCl}$ for 18 hours at $110^{\circ} \mathrm{C}$. The hydroxyproline content was measured by the technique described by Woessner. ${ }^{29}$

DETERMINATION OF PROLYL HYDROXYLASE (EC

1.14.11.2) ACTIVITY

The preparation of prolyl hydroxylase substrate (procollagen) and the method for prolyl hydroxylase assay are described in our previous paper. ${ }^{30}$ Briefly, tibias freshly isolated from 10 day old chicken embryos were labelled with $\left[{ }^{3} \mathrm{H}\right]$-proline in culture medium at $37^{\circ} \mathrm{C}$ for six hours. After removing the unincorporated label by washing, the tissue was homogenated and centrifuged at $3000 \mathrm{~g}$ for 20 minutes at $4^{\circ} \mathrm{C}$. The resulting supernatant was dialysed extensively to remove the unincorporated label. The labelled procollagen substrate was aliquoted and stored at $-70^{\circ} \mathrm{C}$. The incubation mixture for the enzyme assay in a total volume of $2 \mathrm{ml}$ consisted of ferrous ammonium sulphate $(0.1 \mathrm{mmol} / \mathrm{l}), \alpha$-ketoglutaric acid $(0.1 \mathrm{mmol} / \mathrm{l})$, $\left[{ }^{3} \mathrm{H}\right]$-proline procollagen $(200000 \mathrm{dpm})$, lung homogenate $(0.2 \mathrm{ml})$, ascorbic acid $(0.5 \mathrm{mmol} / \mathrm{l})$, and Tris-HCl buffer $(0.1 \mathrm{~mol} / \mathrm{l}$, $\mathrm{pH}$ 7.8). The reaction was started by the addi-

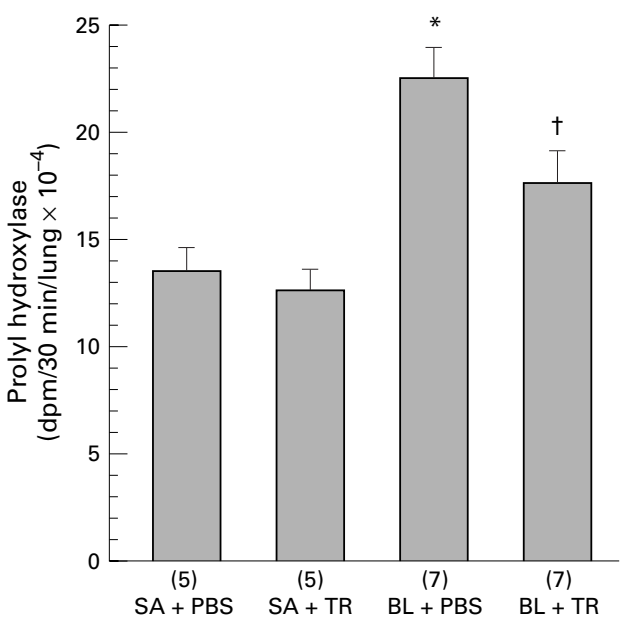

Figure 4 Effects of TGF- $\beta$ soluble receptor treatment on bleomycin induced increases in prolyl hydroxylase activity of hamster lungs. The numbers of animals in each group are shown in parentheses along the $x$ axis. $S A+P B S=$ saline $+P B S$ control; $S A+T R=$ saline $+T G F-\beta$ soluble receptor; $B L+P B S=$ bleomycin $+P B S ; B L+T R=$ bleomycin $+T G F-\beta$ soluble receptor. Values are expressed as mean (SE). ${ }^{*} p<0.05$ compared with all other groups; tp<0.05 compared with $S A+P B S$ and $S A+T R$ groups. 
Table 1 Effects of TGF- $\beta$ soluble receptor (TR) treatment on bleomycin (BL) induced changes in total and differential cell counts of hamster BAL fluid

\begin{tabular}{lllcc}
\hline $\begin{array}{l}\text { Treatment groups } \\
(N)\end{array}$ & $\begin{array}{l}\text { Total cells } \\
\left(\times 10^{-3}\right)\end{array}$ & $\begin{array}{l}\text { Macrophages } \\
\left(\times 10^{-3}\right)\end{array}$ & $\begin{array}{l}\text { Neutrophils } \\
\left(\times 10^{-3}\right)\end{array}$ & $\begin{array}{l}\text { Lymphocytes } \\
\left(\times 10^{-3}\right)\end{array}$ \\
\hline SA+PBS (5) & $1490(153)$ & $1420(150)$ & $55(10)$ & $18(3)$ \\
SA+TR (5) & $1449(206)$ & $1330(180)$ & $88(32)$ & $27(8)$ \\
BL+PBS (7) & $4773(468) \dagger$ & $4090(400)+\dagger$ & $423(98) \dagger$ & $258(46) \dagger$ \\
BL+TR (7) & $6217(683)^{\star}$ & $4060(580)+\dagger$ & $1756(236)^{\star}$ & $397(66)^{\star}$ \\
\hline
\end{tabular}

Values are expressed as mean (SE). The numbers of animals in each group are shown in parentheses following the treatment group.

$\mathrm{SA}+\mathrm{PBS}=$ saline $+\mathrm{PBS}$ control; $\mathrm{SA}+\mathrm{TR}=$ saline $+\mathrm{TGF}-\beta$ soluble receptor $; \mathrm{BL}+\mathrm{PBS}=$ bleomycin + PBS; $\mathrm{BL}+\mathrm{TR}=$ bleomycin $+\mathrm{TGF}-\beta$ soluble receptor.

$\star$ Significantly higher than all other groups $(\mathrm{p}<0.05)$.

†Significantly higher than SA + PBS and SA + TR groups but lower than BL + TR group $(\mathrm{p}<0.05)$.

t†Significantly higher than SA + PBS and SA + TR groups $(\mathrm{p}<0.05)$.

tion of ascorbic acid and stopped by adding $0.2 \mathrm{ml}$ of $50 \%$ trichloroacetic acid after 30 minutes at $37^{\circ} \mathrm{C}$ in a Dubnoff metabolic shaker. During the reaction tritiated water is released in stoichiometric proportion to prolyl hydroxylation and it is used as a measure of the enzyme activity. The tritiated water of the reaction system was separated by vacuum distillation of the whole reaction mixture and counted for radioactivity. The enzyme activity was expressed as dpm ${ }^{3} \mathrm{H}_{2} \mathrm{O}$ released per total lung per 30 minutes.

DETERMINATION OF CELL COUNTS IN BAL FLUID The total and differential cell numbers in the BAL fluid were determined as previously described. ${ }^{5}$ Briefly, total leucocyte numbers in the BAL fluid were estimated by Coulter counter (Model F, Coulter Electronics Inc, Hialeah, Florida, USA) according to the user's manual. Slides for differential cell counts were prepared on a Shandon cytospin using $100 \mu$ l lavage fluid and stained with Diff-Quik (American Scientific, McGaw Park, Illinois, USA). Differential cell counts were performed on a Zeiss microscope at $\times 630$. Macrophages, neutrophils, and lymphocytes were counted based on 400 cells per slide.

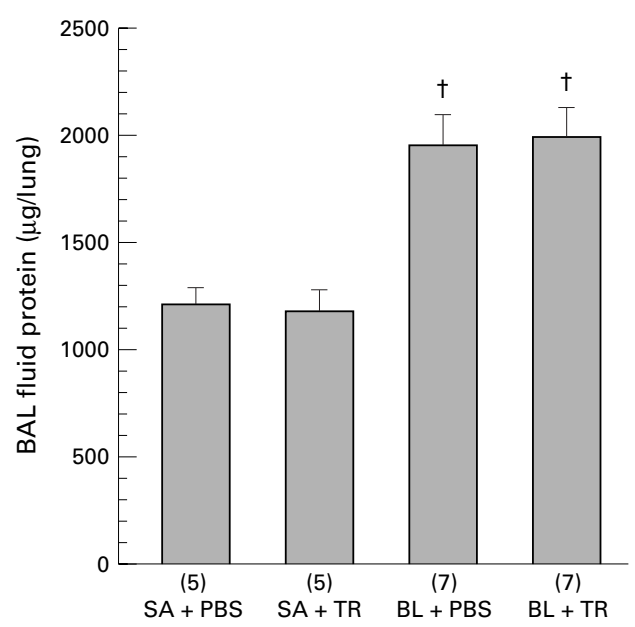

Figure 5 Effects of TGF- $\beta$ soluble receptor treatment on bleomycin induced increases in BAL fluid protein content of hamster lungs. The numbers of animals in each group are shown in parentheses along the $x$ axis. $S A+P B S=$ saline $+P B S$ control; $S A+T R=$ saline $+T G F-\beta$ soluble receptor; $B L+P B S=$ bleomycin $+P B S ; B L+T R=$ bleomycin $+T G F-\beta$ soluble receptor. Values are expressed as mean (SE). $t p<0.05$ compared with $S A+P B S$ and $S A+T R$ groups.
BAL FLUID PROTEIN ASSAY

Protein content in the BAL fluid supernatant was determined using the Bio-Rad protein assay (Bio-Rad Laboratories, Richmond, California, USA) and bovine serum albumin was used as the standard.

HISTOPATHOLOGICAL ANALYSIS

Three animals from each of the SA + PBS and $\mathrm{SA}+\mathrm{TR}$ groups and four animals from each of the BL + PBS and BL + TR groups were randomly chosen for histopathological evaluation at the end of the experiment. The abdominal cavity of the animal was opened and the descending abdominal aorta exsanguinated. Immediately thereafter the lung tissue was prepared for histological analysis as described elsewhere. ${ }^{5}$ Briefly, after cannulating the trachea with a blunt needle the thoracic cavity was opened and both the heart and lung were removed en bloc. The lungs were fixed with $\mathrm{Z}$-fix solution via the trachea at a pressure of $30 \mathrm{~cm} \mathrm{H}_{2} \mathrm{O}$. Before embedding the lung tissue the heart and all non-pulmonary tissue were isolated by blunt dissection and removed. The right cranial and caudal lobes and the left lobe were later blocked, embedded in paraffin, cut in $7 \mu \mathrm{m}$ sections, and stained with haematoxylin and eosin. The lung parenchyma was examined under the microscope. Parenchymal lesions were defined as thickening of interalveolar septa due to oedematous swelling, inflammatory cells, or fibrosis associated with hyperplastic epithelial cells.

\section{STATISTICAL ANALYSIS OF DATA}

All data were expressed on a per total lung basis, which avoids the artefactual lowering of the values in treated animals due to the presence of proteins of extrapulmonary origin. ${ }^{31}$ All values are reported as mean (SE). The data were compared within the four groups using two way analysis of variance (SIGMASTAT) and the Student-NewmanKeuls method. A p value of less than 0.05 was considered significant.

\section{Results}

TYPE II TGF- $\beta$ SOLUBLE RECEPTOR (TR) PRODUCTION

The TR was generated from a recombinant rabbit TGF $\beta$ R:Fc fusion gene comprised of the extracellular domain of the rabbit type II TGF- $\beta$ receptor fused to the $F_{c}$ portion of human $\operatorname{IgG}_{1}$ (fig 1 ). The purified dimeric form of the TR was used in the present study.

BIOLOGICAL ACTIVITY OF THE TYPE II TGF- $\beta$ SOLUBLE RECEPTOR

The biological activity of the TR was determined by a mink lung epithelial cell proliferation assay. When cells were allowed to proliferate in media alone, the amount of $\left[{ }^{3} \mathrm{H}\right]$ thymidine incorporated was measured as 188745 counts per minute (cpm). When TGF- $\beta_{1}$ was included in the media, proliferation was inhibited and the amount of $\left[{ }^{3} \mathrm{H}\right]$ thymidine incorporated was measured as 49088 cpm. As shown in fig 2, TGF $\beta R: F c$ relieved $50 \%\left(\mathrm{IC}_{50}\right)$ of TGF- $\beta_{1}$ mediated inhibition of 


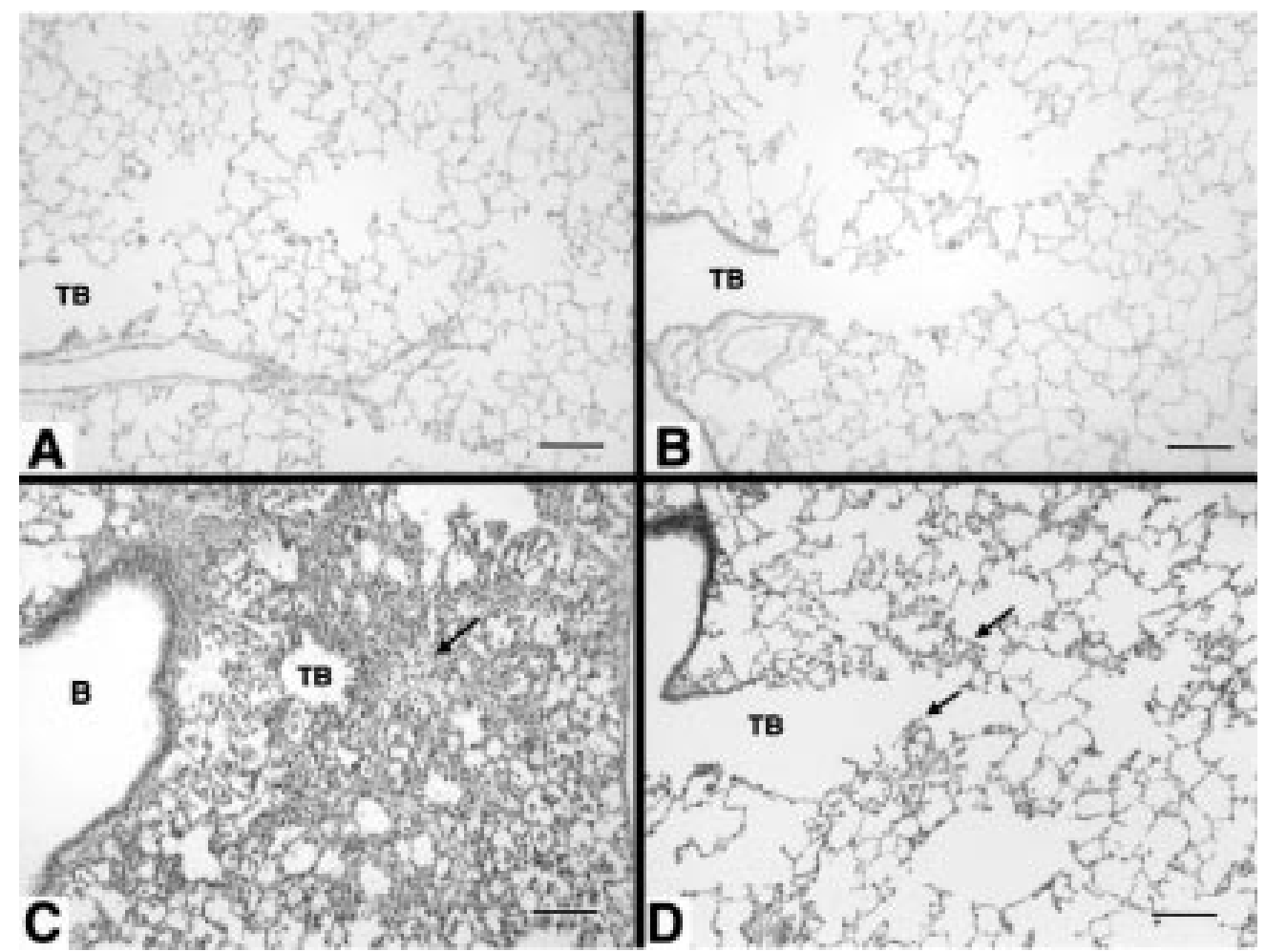

Figure 6 (A) Representative photomicrograph of pulmonary proximal acini from a hamster in the $S A+P B S$ group. (B) Representative photomicrograph of pulmonary proximal acini from a hamster in the $S A+T R$ group. Note the normal appearance of the thin interalveolar septa acinus and the lack of inflammatory cells and fibrosis in both $A$ and $B$. (C) Representative photomicrograph of pulmonary proximal acini from a hamster in the $B L+P B S$ group. Note the multifocal thickening of interalveolar septa by mononuclear phagocytes and fibroblasts. Arrow points to an area of organised connective tissue. (D) Representative photomicrograph of pulmonary proximal acini from a hamster in the BL $+T R$ group. Note the largely normal appearance of parenchyma and only moderate thickening of interalveolar septa and aggregation of mononuclear phagocytes (arrows). Paraffin sections, stain: haematoxylin and eosin. $B=$ bronchus; TB = terminal

bronchiole. Bar $=100 \mu \mathrm{m}$.

proliferation at a concentration of $2 \mathrm{nM}$. The control did not block the inhibitory effect of TGF- $\beta_{1}$ at any of the concentrations tested.

ANIMAL BODY WEIGHT

The average starting body weight of the hamsters used in the study was $125 \mathrm{~g}$ and was similar in the four experimental groups. The hamsters in the SA + PBS and SA + TR groups gained an average of about $7 \mathrm{~g}$ per animal while the animals in the BL + PBS and BL + TR groups that received intratracheal $\mathrm{BL}$ had lost about $2 \mathrm{~g}$ by the end of the experiment. There were no deaths in any of the treatment groups. Treatment with TR did not cause any apparent toxicity or changes in body weight compared with the respective PBS treated controls.

\section{LUNG HYDROXYPROLINE CONTENT}

Lung hydroxyproline, the index of lung collagen level, was determined for the four groups of hamsters and the results are presented in fig 3 . The intratracheal instillation of $\mathrm{BL}$ significantly increased the lung hydroxyproline level in the BL + PBS group to $195 \%$ of the SA + PBS control group. The BL induced increase in the lung hydroxyproline level in the BL + TR group was decreased significantly $(\mathrm{p}<0.05)$ by $33 \%$ by the treatment of TR compared with the BL + PBS group. However, the lung hydroxyproline level in the BL + TR group was still significantly higher than that in the two control groups (SA + PBS and SA + TR).
Treatment with TR alone had no significant effect on lung collagen level when compared with the PBS control in the saline instilled hamsters (SA + TR vs SA + PBS groups).

PROLYL HYDROXYLASE ACTIVITY

The prolyl hydroxylase activities in the hamster lungs of the four groups are shown in fig 4. BL alone significantly increased the lung prolyl hydroxylase activity in the BL + PBS group to $167 \%$ of the SA + PBS control group. TR significantly decreased the prolyl hydroxylase activity increased by the BL treatment in the $\mathrm{BL}+\mathrm{TR}$ group. However, the prolyl hydroxylase activity in the BL + TR group was still significantly higher than that in the two control (SA + PBS and SA + TR) groups. Treatment with TR had no significant effect on the prolyl hydroxylase activity in the saline instilled lungs since there was no significant difference in the activity of this enzyme between the two control groups (SA + PBS and SA + TR).

TOTAL AND DIFFERENTIAL BAL FLUID CELL COUNTS

The total and differential cell numbers in the BAL fluid of the four groups at 20 days after intratracheal instillation of saline or BL are summarised in table 1 . BL treatment increased the total cell counts in the BAL fluid from animals in the $\mathrm{BL}+\mathrm{PBS}$ and $\mathrm{BL}+\mathrm{TR}$ groups compared with the saline control groups (SA + PBS and SA + TR). TR had no effect on the 
saline instilled hamster lungs since there was no significant difference in the cell counts between the two control (SA + PBS and SA + TR) groups. Interestingly, treatment with TR further increased the number of total cells in the BL + TR group compared with the BL + PBS group. Intratracheal instillation of $\mathrm{BL}$, with or without TR, caused increases in the BAL fluid numbers of macrophages, neutrophils, and lymphocytes in the BL + PBS and $\mathrm{BL}+\mathrm{TR}$ groups. Furthermore, the numbers of neutrophils and lymphocytes in the BL + TR group were even higher than those of the BL + PBS group.

PROTEIN CONTENT IN THE BAL FLUID

The protein content of the BAL fluid supernatant for the four groups is shown in fig 5 . Intratracheal instillation of $\mathrm{BL}$ significantly increased the BAL fluid protein in both the BL $+\mathrm{PBS}$ and BL + TR groups compared with the $\mathrm{SA}+\mathrm{PBS}$ and SA + TR groups. However, treatment with $\mathrm{TR}$ in the BL + TR group did not have any significant effect on the BAL fluid supernatant protein compared with the $\mathrm{BL}+$ PBS group.

HISTOPATHOLOGY

Histological examination of the lungs revealed normal pulmonary parenchymal tissue in the $\mathrm{SA}+\mathrm{PBS}$ and SA + TR groups (fig $6 \mathrm{~A}$ and $\mathrm{B}$ ). However, as shown in fig $6 \mathrm{C}$, the BL-treated hamster lungs from the BL + PBS group showed a patchy alveolitis and multifocal interstitial fibrosis containing an accumulation of extracellular fibres. The lungs of hamsters in this group had thickened interalveolar septa and inflammatory cells in adjacent air spaces. Compared with the BL + PBS group, lungs from the BL + TR group had fewer fibrotic lesions, although some lobes showed a moderate degree of mononuclear cell alveolitis and slight degree of interstitial fibrosis (fig 6D).

\section{Discussion}

TGF- $\beta$ has been singled out as one of the most important mediators in collagen synthesis both in vitro and in vivo. ${ }^{78}$ Evidence has accumulated that an increase in TGF- $\beta$ production is accompanied by, and probably contributes to, the excess collagen accumulation in animal lungs following treatment with BL. ${ }^{13-15}$ Thus, one of the logical therapeutic strategies would be to prevent the TGF- $\beta$ production and/or to block the biological activity of this cytokine in response to BL treatment. We chose to antagonise the TGF- $\beta$ effect by administering the TGF- $\beta$ soluble receptor which binds to TGF- $\beta$ with high affinity without signalling, thus effectively abolishing the biological effect of TGF- $\beta$. We have shown that treatment with the recombinant TGF- $\beta$ soluble receptor significantly reduced the $\mathrm{BL}$ induced increase in accumulation of lung collagen, as indicated by the reduced hydroxyproline level and fibrotic lesions in the $\mathrm{BL}+\mathrm{TR}$ group.

An excess accumulation of collagen in the lung is the hallmark of pulmonary fibrosis. Although the mechanisms of increased collagen production in the fibrotic lungs are not entirely clear, various cytokines released as the result of the inflammatory process contribute to the fibrogenesis. Evidence has accumulated that TGF- $\beta$ plays a crucial role in the extracellular matrix production. Firstly, TGF- $\beta$ can act on fibroblasts to induce chemotaxis, proliferation, and induction of the synthesis and release of the matrix proteins. ${ }^{32}$ Secondly, matrix breakdown is prevented by the induction of protease inhibitors by TGF- $\beta$ such as plasminogen activator inhibitor 1 and tissue inhibitor of metalloproteinase. ${ }^{33}$ Increased TGF- $\beta$ mRNA and protein has been associated with the scarring of skin and fibrotic diseases such as glomerulonephritis and pulmonary fibrosis. ${ }^{34-39}$ Studies of human diseases and animal models have recently provided evidence for an involvement of TGF- $\beta_{1}$ in the pathogenesis of liver, kidney and lung diseases ${ }^{34} 40$ and chronic inflammatory disorders such as cirrhosis, glomerulonephritis, ${ }^{38}$ and pulmonary fibrosis. ${ }^{41}$ Overexpression of TGF- $\beta_{1}$ in pancreatic $\beta$ cells, ${ }^{42}$ the livers of transgenic mice, ${ }^{43}$ or after transfer of TGF- $\beta_{1}$ cDNA to rat lung ${ }^{44}$ resulted in massive fibrosis of the targeted organs. Thus, by inhibiting the effect of TGF- $\beta$, the net amount of collagen accumulated can be reduced. However, it is possible that the inhibitory effect of TR on lung prolyl hydroxylase activity might also be related to the reduction of $\mathrm{BL}$ induced lung collagen accumulation, since a decreased activity of this enzyme parallelled a reduction in the accumulation of lung collagen content. Increases in the prolyl hydroxylase activity in various animal models of lung fibrosis, including BL-rodent, usually precedes the accumulation of collagen in the lung. ${ }^{45}$ The enzyme catalysed hydroxylation of proline is an important post-translational event in the processing of highly cross linked mature collagen fibres. ${ }^{46}$ Inhibition of prolyl hydroxylase activity would allow the deposition of a more pliable and soluble form of collagen which is more susceptible to degradation by intracellular collagenases than cross linked mature collagen fibres.

The generation and characterisation of type II TR have recently been reported. ${ }^{47}$ Type II TR was successfully expressed in yeast and bacteria and shown to be a potent inhibitor for TGF- $\beta_{1}$ and TGF- $\beta_{3}$ but less effective in the neutralisation of TGF- $\beta_{2}{ }^{47}$ Similar to our approach, Komesli et $a l^{48}$ expressed type II TR in mammalian cells as a fusion protein to the Fc region of human immunoglobulin and found that it was able to bind TGF- $\beta_{1}$ and TGF- $\beta_{3}$ but not TGF- $\beta_{2}$. We have shown in the present study that the TR we produced had a strong inhibitory effect on the function of TGF- $\beta_{1}$ although it was unlikely to have a significant effect on TGF- $\beta_{2}$. Since TGF- $\beta_{1}$ appears to be the predominant isoform expressed during experimental pulmonary fibrosis, ${ }^{9}$ the ability of the soluble receptor to abrogate TGF- $\beta_{1}$ could be sufficient to offer a beneficial effect against lung fibrosis. It has recently been reported that direct delivery of the type II TR gene into the target organ can ameliorate experimental glomerulonephritis ${ }^{49}$ and liver fibrosis ${ }^{50}$ in rats. These gene therapy 
studies elegantly demonstrated the effective strategy of targeting TGF- $\beta$ by its soluble receptor in the fibrotic diseases. However, the approach we used in the present study of giving the soluble receptor protein itself appears to be more practical and feasible in terms of controlling the dose and schedule of the treatment.

Although treatment with TGF- $\beta$ soluble receptor decreased the $\mathrm{BL}$ induced increase in lung hydroxyproline level, it failed to retard the inflammatory process. BL treatment increased infiltration of the inflammatory leucocyte into the airway and increased vascular permeability, as shown by the numbers of inflammatory cells in the BAL fluid and the protein content of the BAL fluid supernatant. Treatment with TR did not offer protection against the BL induced increase in BAL fluid cell numbers and protein level. In fact, the BL treated hamsters that received TR had higher total cell, neutrophil, and lymphocyte counts. The mechanism by which TR further increases the BL induced increase in influx of inflammatory cells into the airway is not clear. TR itself does not appear to be chemotactic to inflammatory cells since there was no difference in the BAL fluid cell count between the SA + PBS and SA + TR groups. It is known that TGF- $\beta$ is a strong stimulator of collagen synthesis, but its role in the pathophysiological processes varies depending on the condition; TGF- $\beta$ not only elicits the pro-inflammatory effect but the anti-inflammatory effect as well, ${ }^{51}$ the latter being demonstrated by severe inflammatory reactions of various organs including the lungs in TGF- $\beta$ knockout mice. ${ }^{52}$ Blocking the effect of TGF- $\beta$ during BL induced inflammation therefore may not necessarily reduce the infiltration of inflammatory cells. It is possible that $\mathrm{BL}$ induced TGF- $\beta$ may have anti-inflammatory properties and its blockage may lead to a continuation of the acute inflammatory response. Cytokine induced neutrophil chemoattractant (CINC), produced by mouse and rat bone marrow derived macrophages in vitro upon stimulation with lipopolysaccharide, interleukin $1 \beta$, and tumour necrosis factor $\alpha$, was found to be significantly suppressed by TGF- $\beta .^{5354}$ Since TGF- $\beta$ is produced late in the acute inflammatory response, it may function as an important cytokine in the resolution of acute inflammation. Further support for this concept is the observation that macrophages that have ingested apoptotic cells in vitro inhibit pro-inflammatory cytokine production through autocrine/paracrine mechanisms in part by secretion of TGF- $\beta .^{55}$ Nevertheless, it is still possible for TR to inhibit the effect of TGF- $\beta$ on collagen production even without decreasing the inflammatory cell infiltration. We have showed that reduction of neutrophil sequestration of BL treated lungs by application of nitroglycerin did not offer significant protection against $\mathrm{BL}$ induced lung fibrosis. ${ }^{56}$ Furthermore, repeated influx of neutrophils into the lung by intratracheal instillation of complement $5 \mathrm{a}$ failed to produce lung fibrosis. ${ }^{57}$ Thus, the status of lung inflammatory cells, especially the number of neutrophils, may not be directly related to the collagen level in $\mathrm{BL}$ induced lung fibrosis.

The mechanism of reduced collagen accumulation in BL treated hamster lungs by $\mathrm{TR}$ is not completely clear, but it appears to reside in the ability of TR to bind to TGF- $\beta$ and block its biological activity. The effect of TR in the animal appeared to be specific because intratracheal instillation of an equal amount of bovine serum albumin (BSA) did not have any effect on BL induced lung collagen accumulation in hamsters (the hydroxyproline level being 1839 (53) $\mu \mathrm{g} / \mathrm{lung}$ in the BL+BSA group compared with 1823 (41) $\mu \mathrm{g} / \mathrm{lung}$ in the $\mathrm{BL}+\mathrm{PBS}$ group). The biochemical and histopathological evidence provided in this study support the beneficial effect of TR in ameliorating $\mathrm{BL}$ induced lung fibrosis. It remains to be determined whether any other route of TR administration and/or different dose schedule would also have a similar or better antifibrotic effect in the BL animal model of lung fibrosis. Furthermore, it would be interesting to test whether TR administration offers a beneficial effect in other animal models of fibrotic diseases such as liver fibrosis and glomerulonephritis. To that endeavour, this study provides the first in vivo evidence that TR may have therapeutic potential for the treatment of pulmonary fibrosis.

This work was supported by Biogen Inc, Cambridge, Massachusetts, USA and grant \# RO1 HL56262 from the National Heart, Lung and Blood Institute of the National Institutes of Health, Bethesda, Maryland, USA

1 Weissler JC. Idiopathic pulmonary fibrosis: cellular and molecular pathogenesis. Am f Med Sci 1989;297:91-104.

2 Bowden DH. Unraveling pulmonary fibrosis: the bleomycin model. Lab Invest 1984;50:487-8.

3 Snider GL, Celli BR, Goldstein RH, et al. Chronic interstitial pulmonary fibrosis produced in hamsters by endotracheal bleomycin. Am Rev Respir Dis 1978;117:289-97.

4 Wang O, Giri SN, Hyde DM, et al. Amelioration of bleomycin-induced pulmonary fibrosis in hamsters by combined treatment with taurine and niacin. Biochem combined treatment with

5 Wang Q, Hyde DM, Giri SN. Abatement of bleomycininduced increases in vascular permeability, inflammatory cell infiltration, and fibrotic lesions in hamster lungs by ombined treatment with taurine and niacin. Lab Invest 1992;67:234-42.

6 Giri SN, Wang Q. Mechanisms of bleomycin-induced lung injury. Comments Toxicol 1989;3:145-76.

7 Roberts AB, Sporn MB, Assoian RK, et al. Transforming growth factor type beta: rapid induction of fibrosis and angiogenesis in vivo and stimulation of collagen formation in vitro. Proc Natl Acad Sci USA 1986;83:4167-71.

8 Raghu G, Masta S, Meyers D, et al. Collagen synthesis by normal and fibrotic human lung fibroblasts and the effect of transforming growth factor-beta. Am Rev Respir Dis 1989;140:95-100.

9 Coker RK, Laurent GJ, Shahzeidi S, et al. Transforming growth factors-beta 1 , -beta 2 , and -beta 3 stimulate fibroblast procollagen production in vitro but are differentially expressed during bleomycin-induced lung fibrosis. Am f

10 Raghow R, Postlethwaite AE, Keski-Oja J, et al. Transforming growth factor-beta increases steady state levels of type I procollagen and fibronectin messenger RNAs posttranscriptionally in cultured human dermal fibroblasts. F Clin Invest 1987;79:1285-8.

11 Penttinen RP, Kobayashi S, Bornstein P. Transforming growth factor beta increases mRNA for matrix proteins both in the presence and in the absence of changes in mRNA stability. Proc Natl Acad Sci USA 1988;85:1105-8.

12 McAnulty RJ, Campa JS, Cambrey AD, et al. The effect of transforming growth factor beta on rates of procollagen synthesis and degradation in vitro. Biochim Biophys Acta 1991;1091:231-5.

13 Raghow R, Lurie S, Seyer JM, et al. Profiles of steady state levels of messenger RNAs coding for type I procollagen, elastin, and fibronectin in hamster lungs undergoing bleomycin-induced interstitial pulmonary fibrosis. $\mathcal{f}$ Clin Invest 1985;76:1733-9. 
14 Hoyt DG, Lazo JS. Alterations in pulmonary mRNA encoding procollagens, fibronectin and transforming growth factor-beta precede bleomycin-induced pulmonary fibrosis in mice. I Pharmacol Exp Ther 1988;246: $765-71$

15 Gurujeyalakshmi G, Hollinger MA, Giri SN. Regulation of transforming growth factor-beta 1 mRNA expression by taurine and niacin in the bleomycin hamster model of lung fibrosis. Am $\mathcal{f}$ Respir Cell Mol Biol 1998;18: 334-42.

16 Khalil N, Bereznay O, Sporn M, et al. Macrophage production of transforming growth factor beta and fibroblast collagen synthesis in chronic pulmonary inflammation. $\mathcal{F}$ Exp Med 1989;170:727-37.

17 Giri SN, Hyde DM, Hollinger MA. Effect of antibody to transforming growth factor beta on bleomycin induced
accumulation of lung collagen in mice. Thorax 1993;48: accumulatic

18 Giri SN, Hyde DM, Braun RK, et al. Antifibrotic effect of decorin in a bleomycin hamster model of lung fibrosis. Biochem Pharmacol 1997;54:1205-16.

19 Massague J. Receptors for the TGF-beta family. Cell 1992;69:1067-70

20 Kingsley DM. The TGF-beta superfamily: new members, new receptors, and new genetic tests of function in different organisms. Genes Dev 1994;8:133-46.

21 Ebner R, Chen RH, Lawler S, et al. Determination of type I receptor specificity by the type II receptors for TGF-beta receptor specificity by the type II
or activin. Science 1993;262:900-2.

22 Wrana JL, Attisano L, Wieser R, et al. Mechanism of activation of the TGF-beta receptor. Nature 1994;370:341-7.

23 Vivien D, Attisano L, Wrana JL, et al. Signaling activity of homologous and heterologous transforming growth factorbeta receptor kinase complexes. F Biol Chem 1995;270 $7134-41$

24 Lin HY, Moustakas A, Knaus P, et al. The soluble exoplasmic domain of the type II transforming growth factor (TGF)-beta receptor. A heterogeneously glycosylated protein with high affinity and selectivity for TGF-beta ligands. f Biol Chem 1995;270:2747-54.

25 Goetschy JF, Letourneur O, Cerletti N, et al. The unglycosylated extracellular domain of type-II receptor for transforming growth factor-beta. A novel assay for characterizing ligand affinity and specificity. Eur f Biochem 1996; 241:355-62.

26 Tsang ML, Zhou L, Zheng BL, et al. Characterization of recombinant soluble human transforming growth factorbeta receptor type II (rhTGF-beta sRII). Cytokine 1995;7: 389-97.

27 di Clemente N, Wilson C, Faure E, et al. Cloning, expression, and alternative splicing of the receptor for antiMullerian hormone. Mol Endocrinol 1994;8:1006-20.

28 Miller GT, Hochman PS, Meier W, et al. Specific interaction of lymphocyte function-associated antigen 3 with CD2 can inhibit T cell responses. F Exp Med 1993;178:211-22.

29 Woessner JFJ. The determination of hydroxyproline in tissue and protein samples containing small proportions of this imino acid. Arch Biochem Biophys 1961;93:440-7.

30 Giri SN, Misra HP, Chandler DB, et al. Increases in lung prolyl hydroxylase and superoxide dismutase activities dur-
ing bleomycin-induced lung fibrosis in hamsters. Exp Mol Pathol 1983;39:317-26.

31 Karlinsky JB, Goldstein CH. Fibrotic lung diseases: a perspective. F Lab Clin Med 1980;96:939-42.

32 Roberts AB, Sporn MB. Physiological actions and clinical applications of transforming growth factor-beta (TGFbeta). Growth Factors 1993;8:1-9.

33 Laiho M, Saksela O, Keski-Oja J. Transforming growth factor-beta induction of type-1 plasminogen activator inhibitor. Pericellular deposition and sensitivity to exogenous urokinase. F Biol Chem 1987;262:17467-74.

34 Border WA, Ruoslahti E. Transforming growth factor-beta in disease: the dark side of tissue repair. $\mathcal{F}$ Clin Invest 1992; 90:1-7.

35 Border WA, Noble NA. Transforming growth factor beta in tissue fibrosis. N Engl f Med 1994;331:1286-92.

36 Raghow R. The role of extracellular matrix in postinflammatory wound healing and fibrosis. FASEB $\neq$ 1994;8: $823-31$.
37 Santana A, Saxena B, Noble NA, et al. Increased expression of transforming growth factor beta isoforms (beta 1 , beta 2 , of transforming growth factor beta isoforms (beta 1, beta 2 , Respir Cell Mol Biol 1995;13:34-44.

38 Yamamoto T, Noble NA, Cohen AH, et al. Expression of transforming growth factor-beta isoforms in human glomerular diseases. Kidney Int 1996;49:461-9.

39 Ghahary A, Shen YJ, Scott PG, et al. Enhanced expression of mRNA for transforming growth factor-beta, type I and type III procollagen in human post-burn hypertrophic scar tissues. F Lab Clin Med 1993;122:465-73.

40 Border WA, Noble NA. Cytokines in kidney disease: the role of transforming growth factor-beta. Am $\mathcal{F}$ Kidney Dis 1993; 22:105-13.

41 Broekelmann TJ, Limper AH, Colby TV, et al. Transforming growth factor beta 1 is present at sites of extracellular matrix gene expression in human pulmonary fibrosis. Proc Natl Acad Sci USA 1991;88:6642-6.

42 Sanvito F, Nichols A, Herrera PL, et al. TGF-beta 1 overexpression in murine pancreas induces chronic pancreatitis and, together with TNF-alpha, triggers insulin- dependent diabetes. Biochem Biophys Res Commun 1995;217:1279-86.

43 Kopp JB, Factor VM, Mozes M, et al. Transgenic mice with increased plasma levels of TGF-beta 1 develop progressive increased plasma levels of TGF-beta 1 devel.

44 Sime PJ, Xing Z, Graham FL, et al. Adenovector-mediated gene transfer of active transforming growth factor-beta 1 nduces prolonged severe fibrosis in rat lung. $\mathcal{F}$ Clin Invest 1997;100:768-76.

45 Kelley J, Newman RA, Evans JN. Bleomycin-induced pulmonary fibrosis in the rat. Prevention with an inhibito of collagen synthesis. F Lab Clin Med 1980;96:954-63.

46 Miller RL, Udenfriend S. Hydroxylation of proline residues in collagen nascent chains. Arch Biochem Biophys 1970;139: $104-13$.

47 Glansbeek HL, van Beuningen HM, Vitters EL, et al. Expression of recombinant human soluble type II transforming growth factor-beta receptor in Pichia pastoris and Escherichia coli: factor-beta receptor in Pichia pastoris and inhibitor of transforming growth factor-beta. Protein Expr Purif 1998;12:201-7.

48 Komesli S, Vivien D, Dutartre P. Chimeric extracellular domain type II transforming growth factor (TGF)-beta eceptor fused to the $\mathrm{Fc}$ region of human immunoglobulin as a TGF-beta antagonist. Eur f Biochem 1998;254:50513.

49 Isaka Y, Akagi Y, Ando Y, et al. Gene therapy by transforming growth factor-beta receptor-IgG Fc chimera suppressed extracellular matrix accumulation in experimental glomerulonephritis. Kidney Int 1999;55:465-75.

50 Qi Z, Atsuchi N, Ooshima A, et al. Blockade of type beta transforming growth factor signaling prevents liver fibrosis and dysfunction in the rat. Proc Natl Acad Sci USA 1999;96:2345-9.

51 Clark DA, Coker R. Transforming growth factor-beta (TGF-beta). Int $\mathcal{F}$ Biochem Cell Biol 1998;30:293-8.

52 Kulkarni AB, Huh CG, Becker D, et al. Transforming growth factor beta 1 null mutation in mice causes excessive inflammatory response and early death. Proc Natl Acad Sci inflammatory respon

53 Crippen TL, Riches DW, Hyde DM. Differential regulation of the expression of cytokine-induced neutrophil chemoattractant by mouse macrophages. Pathobiology 1998;66:2432

54 Crippen TL, Klasing KC, Hyde DM. Regulation of cytokine-induced neutrophil chemoattractant in rat bone marrow-derived macrophages by inflammatory mediators. Pathobiology 1998;66:293-301.

55 Fadok VA, Bratton DL, Konowal A, et al. Macrophages that have ingested apoptotic cells in vitro inhibit proinflammatory cytokine production through autocrine/paracrine mechanisms involving TGF-beta, $\mathrm{PGE}_{2}$, and $\mathrm{PAF}$. 7 Clin Invest 1998;101:890-8.

56 Wang Q, Haynam DR, Hyde DM, et al. Reduction of bleomycin-induced sequestration of neutrophils and vascular injury in hamster lungs by nitroglycerin. Inflammopharmacol 1992;1:249-61.

57 Harris JA, Hyde DM, Wang Q, et al. Repeated episodes of $\mathrm{C} 5 \mathrm{a}$-induced neutrophil influx do not result in pulmonary fibrosis. Inflammation 1991;15:233-50. 